\title{
Effects of Different Catfish Pituitary Gland Extract Dosages on Eggs and Hatchlings Quantity of African Catfish, Clarias gariepinus at a Constant Latency Period
}

\section{Sebastian S Moshaand ${ }^{1 \star}$ and Frank T Mlingi ${ }^{2}$}

${ }^{1}$ Department of Agriculture, Ministry of Agriculture Training Institute (MATI), P.O. Box-121, Mtwara, Tanzania

${ }^{2}$ Department of Animal, Aquaculture and Range Sciences (DAARS), Sokoine University of Agriculture (SUA), P.O Box-3004, Morogoro, Tanzania

\begin{abstract}
An experiment was conducted to assess the effects of different dosages of catfish pituitary glands extract (CPGE) on eggs and hatchlings quantity of African catfish, Clarias gariepinus at a constant latency period. In this experiment, four dosages $(2 \mathrm{mg} / \mathrm{kg}, 3 \mathrm{mg} / \mathrm{kg}, 4 \mathrm{mg} / \mathrm{kg}$ and $5 \mathrm{mg} / \mathrm{kg}$ of female) were used. Each dosage extracted from a male ( $300 \mathrm{~g}$ to $305 \mathrm{~g}$ ) was injected to individual female $(350 \mathrm{~g}$ to $355 \mathrm{~g})$ at three replications and a total of 12 females were injected. The females were striped after 17 hour at $26^{\circ} \mathrm{C}$ to $28^{\circ} \mathrm{C}$, eggs were counted and incubated. After for 24 hours of incubation at $26^{\circ} \mathrm{C}$ to $28^{\circ} \mathrm{C}$, all hatchlings were counted and recorded. The results indicated that there were significant differences $(P<0.05)$ among the dosages on egg and hatchlings quantity. Egg weight, egg number and percentage egg weight were significantly $(P<0.05)$ higher in dosage three $(4 \mathrm{mg} / \mathrm{kg})$ compared to other treatments. Total hatchlings and percentage hatchlings produced from striped females were significantly $(\mathrm{P}<0.05)$ higher compared to other dosages. In conclusion, the experiment indicated that higher eggs and hatchlings quantity at a constant latency period are attained with $4 \mathrm{mg} / \mathrm{kg}$ of female. Therefore, it is recommended that for better induction of ovulation in African catfish, $4 \mathrm{mg} / \mathrm{kg}$ of female pituitary gland extract should be used as suggested by this study.
\end{abstract}

Keywords: African catfish (C. gariepinus); Catfish pituitary gland extract (CPGE); Dosages; Egg weight; Hatchlings

\section{Introduction}

Demand for fish in both rural and urban areas is very high and continues to grow in Tanzania by FAO in 2007 [1]. The African catfish (Clarias gariepinus) has gained popularity in the aquaculture sector of Tanzania in the recent times [2,3]. Its demand has increased as food, control of over-population in tilapia ponds and as bait for the Nile perch fishery [4-7]. Most fish farmers in Tanzania and other developing countries have to obtain their seeds from wild capture, mainly from rivers. This is due to the constraints that, there are few number of operating hatcheries, low level of technology in larval rearing and live feed production. However, the availability of fry supplies from the wild dependent on seasons and fluctuates with environmental and climatic conditions. Therefore, fish farmers then naturally turns to other means of obtaining there seed stock by hormonal stimulation of the conditions necessary for the fish reproduction in captivity [8]. Hormonal induction of reproduction is necessary for the catfish to overcome atresia. This is done either by injection of pituitary gland from the donor fish of equivalent weight to the female spawned [9-12] or by injection of synthetic gonadotrophin releasing hormone analogues (GNRH-a). Pituitary gland is the main source of the major hormones responsible for reproduction in animals. The pituitary cells have been reported to undergo continuous mitotic process [13]. The pituitary gland can be cultured and proliferated in vitro in order to use their secretions for induction of spawning in catfish [14-16]. The synthetic equivalents are also used to induce ovulation in African catfish. However, most of the hormones that are generally used are deficient in many ways, such as Deoxycorticosteroid Acetate (DOCA) causes severe ulcer on the injected female and Human Chronic Gonadotropin (HCG) is expensive [14]. In contrary to pituitary gland extract which is recommended to use pituitary gland from the donor fish of equivalent weight to the female spawned [17], most of the synthetic hormones have recommended dosage for different fish species. For instance, In Indian major carp, a brood male and female administered with $0.1-0.2 \mathrm{ml} / \mathrm{kg}$ and $0.25-0.5$ $\mathrm{ml} / \mathrm{kg}$ body weight of Ovaprim respectively. While $0.1-0.3 \mathrm{ml} / \mathrm{kg}$ and $0.2-0.5 \mathrm{ml} / \mathrm{kg}$ Ovatide can be administered to male and female brood stock respectively. For Ovopel, Catla and Rohu are administered 1-2 pellet/kg and Human Chorionic Gonadotropin (HCG), 500-6000 IU/kg body weight of fish can be administered [15]. A lot of progress has been made so far in aquaculture and advancement of technology regarding ovulation and spawning induction for some important commercial finfish. However, the exactly catfish pituitary grand extract dosage for ovulation and spawning induction remains the bottleneck in $C$. gariepinus production. The proper use of quantified catfish pituitary gland extract dosage seems to be one of the solutions to improve egg quantity and hatching rate. Therefore, the experiment was designed to determine recommended dosage of African catfish pituitary gland extract to induce ovulation and improving the quantity of egg and hatchlings of African catfish.

\section{Materials and Methods}

The experiment was conducted for one week, from the last week of September 2017 at aquaculture research facility in Magadu farm at Sokoine University of Agriculture (SUA), Morogoro, Tanzania. The experiment involved determination of eggs and hatchlings of quantity produced at four different catfish pituitary extract dosages $(2.0 \mathrm{mg} / \mathrm{kg}$,

*Corresponding author: Sebastian S Moshaand, Department of Agriculture, Ministry of Agriculture Training Institute (MATI), P.O. Box-121, Mtwara Tanzania, Tel: +255 783372 900; E-mail: seblym2012@yahoo.com

Received March 09, 2018; Accepted March 24, 2018; Published March 27, 2018

Citation: Moshaand SS, Mlingi FT (2018) Effects of Different Catfish Pituitary Gland Extract Dosages on Eggs and Hatchlings Quantity of African Catfish, Clarias gariepinus at a Constant Latency Period. J Aquac Res Development 9: 526. doi: 10.4172/2155-9546.1000526

Copyright: (c) 2018 Moshaand SS, et al. This is an open-access article distributed under the terms of the Creative Commons Attribution License, which permits unrestricted use, distribution, and reproduction in any medium, provided the original author and source are credited. 
Citation: Moshaand SS, Mlingi FT (2018) Effects of Different Catfish Pituitary Gland Extract Dosages on Eggs and Hatchlings Quantity of African Catfish, Clarias gariepinus at a Constant Latency Period. J Aquac Res Development 9: 526. doi: 10.4172/2155-9546.1000526

Page 2 of 3

$3.0 \mathrm{mg} / \mathrm{kg}, 4.0 \mathrm{mg} / \mathrm{kg}$ and $5.0 \mathrm{mg} / \mathrm{kg}$ ) administered to females with three replications per dosage. The experiment didn't consider uninjected females as a control because the aim was to test the efficiency of different catfish pituitary gland extract dosages under artificial reproduction.

\section{Determination of eggs and hatchling quantity produced at a constant latency period}

Selection of breeders: Twelve (12) ripe females (350 g to $355 \mathrm{~g}$ ) having a well distended and swollen abdomen which released eggs when gently pressed were selected. Each female was kept into separate plastic tanks (30 lt) without fed for 8 hours before pituitary extract hormonal injection. Also, twenty (20) males (300 g to $305 \mathrm{~g}$ ) were selected for provision of sperm and pituitary gland extraction.

Catfish pituitary gland extract: The pituitary glands were extracted and collected from six males under the brain mass after sacrificed and the top part of the head skull removed by using sharp knife as described by De Graaf and Janssen in 1996. Then, pituitary glands extracted were weighed and four different dosages $(2.0 \mathrm{mg} / \mathrm{kg}, 3.0 \mathrm{mg} / \mathrm{kg}, 4.0 \mathrm{mg} / \mathrm{kg}$ and $5.0 \mathrm{mg} / \mathrm{kg}$ ) were obtained.

Hormonal preparation and injection: Each pituitary grand extract dosage was grounded in a porcelain mortar and mixed with 1 $\mathrm{ml}$ of normal salt solution ( $9 \mathrm{~g}$ of common salt per 1lt of water). Then, $1 \mathrm{ml}$ of a mixture was filled to the syringe and injected to a female intramuscularly. The procedures repeated for all four dosages and each dosage had replicated trice ( 3 replicates per treatment/dose). Therefore, a total of twelve (12) females were injected with four dosages (1 dose per female with three replications). After the injections, each female was returned to the plastic tank $(30 \mathrm{lt})$ and left for 17 hours at a $26^{\circ} \mathrm{C}$ to $28^{\circ} \mathrm{C}$.

Striping of eggs, sperm extraction and fertilization: Stripping of the females was carried out by gently pressing the abdomen with a thumb from the pectoral fin towards the genital papilla. The ovulated eggs flowed out easily in a thick jet from the genital vent and collected into a clean and dry plastic container, weighed and counted according to Kraak et al. [9]. Data from each female per dosage stripped were recorded. Milts were obtained by sacrificing 12 males and the testes from each male were surgically removed and cut into small pieces, oozed out and added to the stripped eggs then stirred with a feather. For every amount of eggs collected from individual striped female per dosage were fertilized by a single male. Then, equal volume of clean water was added to the egg's container mixed by gently shaking the bowl. Eggs were stirred continuously for about 60 seconds to facilitate fertilization and to avoid stickiness once contacted with water.

Incubation and hatching of fertilized eggs: Incubation of the fertilized eggs was done by spreading the eggs from each female per dosage separately on nets which were fixed on plastic tanks (30 lt). Then, a continuous flowing of water into and from each tank was maintained to ensure constant supply of fresh water with oxygen. The eggs were incubated for 24 hours at $26^{\circ} \mathrm{C}-28^{\circ} \mathrm{C}$. Incubation systems were arranged according to the dosages applied respectively (eggs from each female/dosage/tank).

Data collection: After 24 hours of incubation, the hatchlings from each female/dosage/tank were siphoned in the syringe. Hatchlings in one syringe were counted and recorded. The total hatchlings from each syringe were calculated by multiplying the number of larvae obtained earlier in the syringe with total number of syringe obtained.

\section{Statistical data analysis}

One-way analysis of variance (ANOVA) was used to compare differences between treatment means at $5 \%$ level of significance. Posthoc analysis was done where significant differences existed between treatments means using Tukey's test. Analyses were performed using SAS (1998) software.

\section{Results}

Effect of different pituitary gland extract dosages on the quantity of eggs and hatchlings at a constant latency period

The results indicated that, there were significant differences $(\mathrm{P}<0.05)$ among the doses as expressed as dose per $\mathrm{kg}$ on egg and hatchlings parameters (Tables 1 and 2) (Figure 1). Among parameters, egg weight, egg number and percentage egg weight were significantly $(\mathrm{P}<0.05)$ higher in treatment/dosage $3(4 \mathrm{mg} / \mathrm{kg})$ compared to other treatments (Table 1). Also treatment (dosage 3$)(4 \mathrm{mg} / \mathrm{kg})$ was significantly $(\mathrm{P}<0.05)$ higher in total hatchlings and percentage hatchlings produced from striped females compared to other treatments (Table 2).

\section{Discussion}

The results indicated that as pituitary gland extract dosages increased, egg and hatchling quantity were also increases. Comparable results have been reported by Fagbenro et al. [6]. This is likely due to the increased in concentration of dose which had the satisfactory action on the female's gonads. According to Chen et al. [3], the synchronization of ovulation in fish after the application of pituitary dose is very important aspect. Egg weight, egg number and percentage egg weight were higher in $4 \mathrm{mg} / \mathrm{kg}$ dosage than the other dosages. Similarly, reported higher quantity of eggs in C. gariepinus with pituitary at $4 \mathrm{mg} / \mathrm{kg}$ indicating the high potency of this ovulation agent. This is probably due to the proper activation of Gonadotropin hormone-II (GTH-II) cell present in the Pars distalis of the hormonal injected fish which in turn helps in the proper secretion of GTH-II. The secreted (GTH-II) binds to the specific receptor in the granulose cells of ovary or Leydig cells of testis and subsequently stimulates steroid hormone synthesis in these cells resulting in the better ovulation [10]. Another probable explanation for obtaining better results from fish injected with higher doses of pituitary gland extracts is that, the stimulants in higher doses stimulate the fish effectively by contracting the smooth muscles in the gonoducts of female before ovulation and culminating in spawning of fish [18]. The

\begin{tabular}{|c|c|c|c|}
\hline Dosages & Egg weight & Egg number & $\begin{array}{c}\text { \% egg weight } \\
\text { (Arcin \%) }\end{array}$ \\
\hline $1(2 \mathrm{mg} / \mathrm{kg})$ & $48.56 \pm 23.57^{\mathrm{a}}$ & $27704.36 \pm 13832.65^{\mathrm{a}}$ & $4.20 \pm 0.69^{\mathrm{a}}$ \\
\hline $2(3 \mathrm{mg} / \mathrm{kg})$ & $57.95 \pm 22.25^{\mathrm{a}}$ & $33051.82 \pm 13067.30^{\mathrm{a}}$ & $8.24 \pm 0.65^{\mathrm{a}}$ \\
\hline $3(4 \mathrm{mg} / \mathrm{kg})$ & $174.99 \pm 22.19^{\mathrm{b}}$ & $100823.80 \pm 13033.89^{\mathrm{b}}$ & $16.84 \pm 0.65^{\mathrm{b}}$ \\
\hline $4(5 \mathrm{mg} / \mathrm{kg})$ & $73.60 \pm 23.71^{\mathrm{ab}}$ & $41903.69 \pm 13925.86^{\mathrm{ab}}$ & $13.08 \pm 0.69^{\mathrm{ab}}$ \\
\hline
\end{tabular}

Means with different superscript within columns indicate significant differences (Tukey's multiple range test at $\mathrm{P}<0.05$ )

Table 1: Egg parameters observed in four different dosages) after 17 hours of hormonal injection at $26^{\circ} \mathrm{C}$ to $28^{\circ} \mathrm{C}$ (Mean $\pm \mathrm{SE}$ ).

\begin{tabular}{|c|c|c|}
\hline Dosages & Total hatchlings & \% hatchlings (Arcin \%) \\
\hline $1(2 \mathrm{mg} / \mathrm{kg})$ & $2795.95 \pm 3501.15^{\mathrm{a}}$ & $0.03 \pm 0.11^{\mathrm{a}}$ \\
\hline $2(3 \mathrm{mg} / \mathrm{kg})$ & $4275.54 \pm 3305.05^{\mathrm{a}}$ & $2.05 \pm 0.10^{\mathrm{a}}$ \\
\hline $3(4 \mathrm{mg} / \mathrm{kg})$ & $23517.26 \pm 3296.60^{\mathrm{b}}$ & $2.76 \pm 0.10^{\mathrm{b}}$ \\
\hline $4(5 \mathrm{mg} / \mathrm{kg})$ & $811.25 \pm 3522.20^{\mathrm{ab}}$ & $1.23 \pm 0.11^{\mathrm{ab}}$ \\
\hline
\end{tabular}

Means with different superscript within columns indicate significant differences (Tukey's multiple range test at $\mathrm{P}<0.05$ )

Table 2: Hachlings parameters observed in four different dosages after 24 hours of incubation at $26^{\circ} \mathrm{C}$ to $28^{\circ} \mathrm{C}$ (Mean $\pm \mathrm{SE}$ ). 


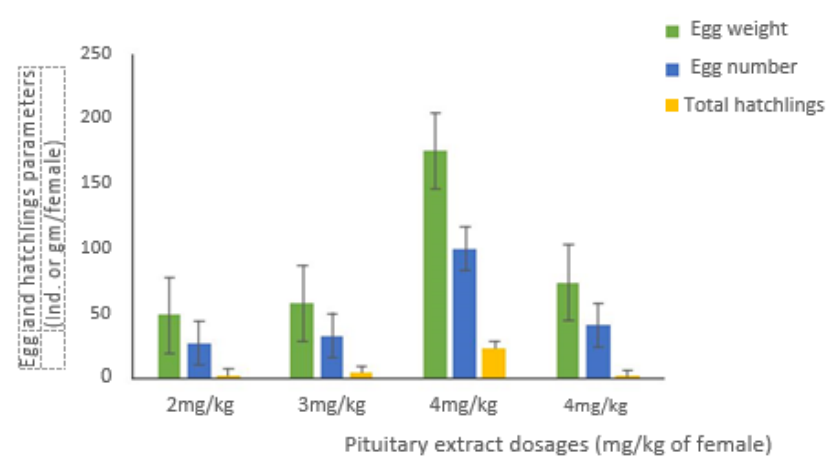

Figure 1: Egg and hatchling parameters measured in four treatments/doses during the experiment.

poor responses at lower dosages of pituitary gland extracts $(2 \mathrm{mg} / \mathrm{kg}$ of female) may be due to insufficient secretion of gonadotropin leading to ovulation failure or blocking of ovipore by disintegrated ovarian tissue and egg bunches [16]. Higher hatchling was observed in $4 \mathrm{mg} / \mathrm{kg}$ of female than other dosages. Comparable results reported by Tripathy et al., Yeung et al., and Zonneveld et al. [17-19]. This may be due to the fact that temperature played an important role to optimize all the physiological activities of the stimulant injected fish [19]. In contrast to these results that, a single intramuscular injection of $6 \mathrm{mg} / \mathrm{kg}$ of carp pituitary extract and a stripping time of 17 hours at $25^{\circ} \mathrm{C}$ gave the best results in artificial propagation of catfish. This was due to fact that, carp pituitary extracts are commonly used in combination with Human Chorionic Gonadotropin (HCG).

\section{Conclusion}

The study indicated that, $4.0 \mathrm{mg} / \mathrm{kg}$ pituitary gland extract dosage of female had highest results in egg weight and hatchling produced compared to $2.0 \mathrm{mg} / \mathrm{kg}, 3.0 \mathrm{mg} / \mathrm{kg}$ and $5.0 \mathrm{mg} / \mathrm{kg}$. Hence it is recommended to use $4.0 \mathrm{mg} / \mathrm{kg}$ dosage for production of large quantity of eggs and higher hatchlings percentage in induction of ovulation of African catfish in aquaculture practices. However, further study can be conducted to compare different CPGE dosages with another solution as a control.

\section{Acknowledgements}

We thank the Department of Animal Science Production, Sokoine University of Agriculture (SUA). Also, the technical inputs of all who participated to accomplish this experiment are greatly acknowledged.

\section{References}

1. Adebayo TO, Popoola MO (2008) Comparative evaluation of efficacy and cost of synthetic and non-synthetic hormones for artificial breeding of African catfish. J Fisheries Aquatic Sci 3: 66-71.

2. Brzuska E (2003) Artificial propagation of European catfish (Silurus glanis): Application of a single dose of pellets containing D-Ala, Pro9NEt-mGnRH and dopamine inhibitor metoclopramide to stimulate ovulation in females of different body weight; Institute of Ichthyobiology and Aquaculture, Polish Academy of Sciences, Golysz, Poland. pp: 152-163.

3. Chen MJ, Chiou PP, Liao Y, Lin C, Chen TT (2010) Development and characterisation of five rainbow trout pituitary single-cell clone lines capable of pituitary hormones. J Endocrinol 205:69-78.

4. Delince GA, Campbell D, Janssen JAL, Kutty MN (1987) UNDP/FAO: Seed production. Nigerian institute for oceanography and marine research project raf/82/009, Nigeria.

5. Dhara K, Saha NC (2013) Controlled breeding of asian catfish clarias batrachus using pituitary gland extracts and ovaprim at different temperatures, latency periods and their early development. J Aquac Res Development 4:186.

6. Fagbenro OA, Salami AA, Sydenham DHL (1998) Induced ovulation and spawning in the catfish, Clarias isheriensis, using pituitary extracts from nonpiscine sources. J Appl Aquact 1: 15-20.

7. Food and Agricultural Organization of the United Nations (2007) The state of word fisheries and aquaculture 2006. FAO Fisheries and Aquaculture Department, Rome, Italy.

8. De Graaf P, Janssen H (1996) FAO: Artificial reproduction and pond rearing of the african catfish clarias gariepinus in sub-Saharan Africa. Nefisco foundation Amsterdam, The Netherlands.

9. Kraak GVD, Chang JR, Janz DM (1998) Reproduction In: Evans DH (eds), The physiology of fishes. (2nd edn), CRC Press, USA.

10. Mosha SS, Kang'ombe J, Jere W, Madalla N (2016) Effect of organic and inorganic fertilizers on natural food composition and performance of african catfish (clarias gariepinus) fry produced under artifcial propagation. J Aquac Res Development 7: 441

11. Musiba MJ, Ngupula GW, Kashindye BB, Elison M, Shoko AP, et al. (2014) Performance of locally formulated feeds for rearing of African catfsh in Tanzania. African Crop Science Journal 22: 979-986.

12. Olaniyi CO, Akinbola DO (2013) Comparative studies on the hatchability, performance andsurvival rate of african catfish (clarias gariepinus) larval produced using ovaprim and catfish pituitary extract hormones. Journal of Biol Agricul Healthcare. 3: 57-62

13. Surnar SR, Kamble AD, Walse NS, Sharma OP, Saini VP (2015) Hormone administration with induced spawning of Indian major carp. Int $\mathrm{J}$ Fisheries Aquatic Studies 3: 1-4.

14. Sahoo SK, Giri SS, Chandra S, Mohapatra BC (2008) Evaluation of breeding performance of Asian catfish clarias batrachus at different dose of hcg and latency period combinations. Turkish J Fish and Aqua Sci 8: 249-251.

15. Salami AA, Fagbenro OA, Balogun AM, Atoyebi O, Olowoyeye MF (2006) Effective dose of amphibian pituitary extracts for the induced spawning of the Clariid Catfish, Clarias gariepinus (Burchell 1822). J Aquac Tropics 11:9-12.

16. Smith LS (1999) Reproduction In: Introduction to Fish Physiology. Narendra Publishing House, New Delhi, India. p: 266.

17. Tripathy SD, Khan HA (1990) Carp seed production technology - A review In keshavanath $\mathrm{p}$, radhakrishnan $\mathrm{kv}$ (eds), carp production technology. special publication. Asian Fish Soc, Indian Branch 2: 1-11.

18. Yeung CM, Chan CB, Leung PS, Cheng CHK (2006) Cells of the anterior pituitary. Int J Biochem Cell Biol 38:1441-1449.

19. Zonneveld N, Rustidja WJ, Viveen AR, Maduna W (1988) Induced spawning egg incubation of Asian Catfish, Clarias batrachus. Aquaculture 74: 41-47. 